\title{
Effects of liposomes containing exogenous recombinant porcine somatotropin on rats
}

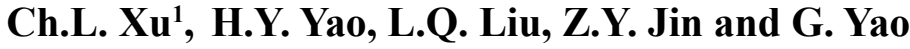 \\ School of Food Science and Technology, Southern Yangtze University \\ Wuxi, Jiangsu, 214036, China
}

(Received 27 May 2005; revised version 15 February 2006; accepted 12 April 2005)

\begin{abstract}
Sixty-four Sprague Dawley (SD) rats were divided randomly into 4 groups of 16 . The control group was injected with physiological saline $(1 \mathrm{ml})$; group 1 was injected with pure porcine somatotropin (PST) daily, $1 \mathrm{ml}$ per rat $(1.2 \mathrm{mg} / \mathrm{ml})$; group 2 was injected with PST liposome every 7 days $(8.4 \mathrm{mg} / \mathrm{ml})$; group 3 was injected with PST liposome every 14 days $(16.8 \mathrm{mg} / \mathrm{ml})$. Porcine somatotropin (PST) and PST liposomes were injected into the abdominal cavity of the rats for 28 days. Both PST and PST liposome stimulated the growth performance of rats. There were, however, significant differences in growth rate and IGF-I content between the treatment and the control groups $(\mathrm{P}<0.05)$; the growth effect of PST liposomes on rats was mediated by the sustained-release formulation used in this experiment. The effect of this formulation lasted more than seven days.
\end{abstract}

KEYWORDS: porcine somatotropin (PST); liposome; growth rate; rats; sustained-release

\section{INTRODUCTION}

Growth hormone (GH) or somatotropin (ST) is a single polypeptide chain consisting of 191 amino acids (around 22,000 Da), varying considerably among species. The growth-promoting effect of GH was shown in rats as early as in the 1920s by Evans and co-workers. They demonstrated that GH increased weight gain (Evans and Simpson, 1987) and stimulated protein accretion concurrently with a reduction in fat deposition (Chen et al., 1999). The effects of liposome GH on growth in mice have been studied (Crommelin et al., 2003). The effect was

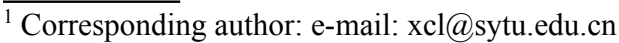


not studied in farm animals until the 1950s. Brumby conducted an experiment in cattle, and Turmann and Andrews (1955) investigated the effects in pigs. For many years it was not possible to apply this knowledge in practice due to the limited supply of GH. With the advent of recombinant DNA techniques this situation has now changed, and porcine GH has been approved since 1995 in Australia (Sejrsen and Oksbjerg, 1995) for commercial use in growing pigs. Recombinant bovine $\mathrm{GH}$ ( $\mathrm{rbST}$ ) is widely used to accelerate milk production in cows, but it is not used commercially for growth promotion. GH cannot be administered orally, but only by injection. For cattle, sustainable release formulations for monthly administration are on the market.

Liposomes are an artificial microscopic vesicle consisting of an aqueous core enclosed in one or more phospholipid layers, used to convey vaccines, drugs, enzymes, or other substances to target cells or organs. They were first used by the English scholars, Bangham et al. (1965), when they studied phospholipids. The partitioning of drugs between cell membranes and aqueous solutions has been widely investigated using liposomes, which are model membranes with a bilayer lipid structure. Multilamellar liposomes (MLVs) have been used in a sedimentation method to study drug-membrane interactions and to determine the membrane partition coefficient for drugs (Betageri and Rogers, 1987; Wolverton et al., 1992). Liposomes can be decomposed in bodies, causing no toxic or immune reactions (Huth et al., 2004). Moreover, as a drug-carrier they can reduce the toxicity of drugs. In recent years researchers have focused on liposomes and rapid progress has been made. Encapsulating PST in liposomes can not only protect drugs from digestive losses but also promote their absorption in a sustained-release manner.

Molecular biology studies have shown that porcine somatotropin (PST) can increase the level of IGF-I (insulin-like growth factor-I) in tissues, mainly by stimulating the liver and muscles to produce IGF-I. PST helps enforce the transcriptional regulation of IGF-IDNA to IGF-ImRNA, producing more IGF-I to accelerate cell differentiation, protein synthesis, and muscle growth. In addition to liver cells, many other tissues (skeletal muscle, adipose tissue, and primitive fatty cells) are able to synthesize IGF-I via autocrine and paracrine mechanisms in response to stimulation by PST. Local IGF-I may play a major part in the growth of bone and cartilage, with PST having a direct effect on targeted tissues in IGFI-dependent circumstances. Some studies have indicated that PST inhibited fattyacid synthetase via the transcription of IGF-ImRNA in fibrous liver and adipose tissues (Mildner and Clarke, 1991; Harris et al., 1993).

The purpose of this study was to examine the metabolic impact of PST liposomes on rats and to offer a theoretical basis for the application of PST liposomes according to animal model, and also to determine the effects on growth rate in rats. 


\section{MATERIAL AND METHODS}

\section{Main instruments}

A ZFA-1 revolving evaporator (sponsored by Shanghai Glass Instrument Second Factory); Ultrasonic processor (intensity $400 \mathrm{~W}$, frequency $20 \mathrm{KHz}$ ) (Sonics \& Materials Vibra Cell); UV755B spectrophotometer (Shanghai Fine Science Instrument Factory).

\section{Preparation of PST liposomes}

Recombinant porcine somatotropin (identical structure as natural porcine somatotropin, provided by Lupeng Bio-technological Center /Shenzhen PRC.); PST liposomes were prepared by the reverse phase evaporation method. 1. Lecithin, cholesterol and octadecane (Fluka) were weighed according to the molecular ratio of 7:2:1 (respectively) and transferred to a round-bottomed flask; 2 . ether $(30 \mathrm{~mL})$ was added and mixed until the substances were completely dissolved; 3 . PST was rehydrated with PBS solution $(25 \mathrm{~mL}, 0.01 \mathrm{~mol} / \mathrm{L})$ until dissolved, 4. the solution was treated for 5 min with ultrasonic waves ( $40 \%$ intensity, at 1s intervals); 5 . the solvents were evaporated under a vacuum at $38^{\circ} \mathrm{C}$ until a gum or membrane consistency was reached and then washed on a membrane with $25 \mathrm{~mL}$ PBS (0.01 mol); 6. evaporation was repeated until all of the ether was removed and the remainder was centrifuged for $5 \mathrm{~min}$ at $3000 \mathrm{rpm}$ to remove superfluous PST. The product was stored under liquid nitrogen.

\section{Animals and treatments}

Sprague-Dawley male and female rats from FuDan Univerisity Medicine School, Shanghai were used in this study. Animal handling procedures were in accordance with guidelines approved by the JiangSu Province Animal Care Committee. Rats were fed preliminarily for 10 days. All rats were fed ad libitum with free access to water and housed under constant temperature $\left(25^{\circ} \mathrm{C}\right)$, controlled lighting (light: 08:00-20:00 h) and relative humidity of 60\%. Bedding (wood scraps) was changed daily. The daily diet was compounded in our laboratory and contained, \%: casein 20 , maize oil 2.5 , lard oil 2.5 , maize starch 63 , cane sugar 6 , cellulose 1 , mineral premix 3.5 and vitamin premix 1.5 .

The rats were divided randomly into 4 groups of 16. Each group had equal numbers of females and males; the sexes were reared in separate boxes (differences in initial body weight less than $3 \mathrm{~g}$ in the same group). The control group was injected with physiological saline $(1 \mathrm{~mL})$ in the abdominal cavity. Group 1 was 
injected with pure PST daily, $1 \mathrm{~mL}$ per rat $(1.2 \mathrm{mg} / \mathrm{mL})$; group 2 was injected with PST liposome every 7 days $(8.4 \mathrm{mg} / \mathrm{mL})$; group 3 was treated with PST liposome every 14 days $(16.8 \mathrm{mg} / \mathrm{mL})$.The same dose of PST with different dosing regimes was intended to demonstrate differences in growth promotion in male and female rats by pure PST and PST liposome. From day 2 on, the rats were weighed at 8.00 a.m. every morning after which the drug was injected according to the experimental protocol.

\section{Concentration of IGF-I in blood plasma}

Following the first injection, the blood was sampled using approximately 0.5 $\mathrm{ml}$ from the auricle veins in all rats. The samples were drawn on the first two days after injection at $1,2,3.5,5.5,7.5,10,16$, and $20 \mathrm{~h}$. On the $3^{\text {rd }}$ day, blood was sampled four times, with blood sampled twice each day on the following 4 days. On the $14^{\text {th }}$ day, blood was sampled at $8,12,16$, and $20 \mathrm{~h}$. The blood samples were centrifuged at $3000 \mathrm{rpm}$ for $5 \mathrm{~min}$ to separate the blood plasma.

For determination of IGF-I, $0.1 \mathrm{ml}$ blood plasma was added to $0.9 \mathrm{ml}$ alcohol acid $(21.6 \mathrm{ml} \mathrm{HCl}, 103.4 \mathrm{ml}$ double-distilled water, $875 \mathrm{ml}$ water-free ethanol for $1 \mathrm{~L}$ solution). The solution was incubated at an ambient temperature for 30 min, centrifuged at $3500 \mathrm{rpm}$ at $4^{\circ} \mathrm{C}$ for $30 \mathrm{~min}$, and the upper $0.2 \mathrm{ml}$ of the supernatant removed and mixed with $0.1 \mathrm{ml}$ Tris buffer $(0.855 \mathrm{M}$ Tris Base; $103.54 \mathrm{~g}$ Tris dissolved in $1 \mathrm{~L}$ double-distilled water, $\mathrm{pH} 11.0$ ). It was then incubated at an ambient temperature for $30 \mathrm{~min}$ prior to centrifuging (30 $\mathrm{min}$, $3500 \mathrm{rpm}, 4^{\circ} \mathrm{C}$ ). Next, the supernatant was removed and mixed with $0.8 \mathrm{ml}$ PBS buffer solution. After alcohol acid was removed, the product was subjected to radioimmunoassay (double antibody RIA): PBS, 125I-IGF-I, Ab1, Ab2, were added to the extract and sequentially incubated $18-24 \mathrm{~h}$ and $16-18 \mathrm{~h}$, respectively. Finally, the concentration of IGF-I $(\mathrm{mg} / \mathrm{ml})$ in each sample was determined with an FMJ-182 RIA kit.

\section{Statistical analysis}

The results are expressed as mean values with standard errors. Gender and indicators of circulating growth hormone levels such as immune-reactive PST were analysed using analysis of variance for a completely randomized design, and differences between means were determined using two-way ANOVA procedures. Multi-comparison was used to test significance and probability values of $\mathrm{P}<0.05$ were taken as significant. 


\section{RESULTS}

\section{IGF-I value in blood plasma}

Following the first day's injection, the IGF-I of groups 1, 2 and 3 increased remarkably, reaching a peak $6 \mathrm{~h}$ later. In comparison with the control group, however, there were no differences on the first day. On the second day, IGF_I concentrations began to rise, reaching a peak at $4.00 \mathrm{a} . \mathrm{m}$. On the $3 \mathrm{rd}$ day, plasma IGF-I levels did not rise for $12 \mathrm{~h}$, since the PST in blood plasma had risen, possibly indicating that the concentration of IGF-I in the blood plasma changes with time and is somehow connected with PST. The IGF-I concentration-time dependence after injection over two days is shown in Table 1 and Figure 1.

Table 1. IGF-I content in plasma of rats in different time between groups, $\mathrm{ng} / \mathrm{ml}$

\begin{tabular}{|c|c|c|c|c|c|c|c|c|}
\hline & \multicolumn{4}{|c|}{ The $7^{\text {th }}$ day } & \multicolumn{4}{|c|}{ The $14^{\text {th }}$ day } \\
\hline & 8:00 & 12:00 & $16: 00$ & 20:00 & 8:00 & $12: 00$ & $16: 00$ & $20: 00$ \\
\hline $\begin{array}{l}\text { Control } \\
\text { group }\end{array}$ & $36 \pm 2.3^{\mathrm{a}}$ & $61.5 \pm 4.7^{\mathrm{a}}$ & $0.5 \pm 5.3^{\mathrm{a}}$ & $59.5 \pm 3.8^{\mathrm{a}}$ & $40 \pm 1.3^{c}$ & $45 \pm 3.2^{c}$ & $55 \pm 3.3^{\mathrm{c}}$ & $58 \pm 4.1^{\mathrm{c}}$ \\
\hline Group 1 & $99 \pm 4.1^{b}$ & $99 \pm 4.1^{b}$ & $84.5 \pm 4.8^{b}$ & $147 \pm 6.7^{b}$ & $121 \pm 2.6^{\mathrm{d}}$ & $284 \pm 3.5^{\mathrm{d}}$ & $93 \pm 6.2^{\mathrm{d}}$ & $192 \pm 7.8^{\mathrm{d}}$ \\
\hline Group 2 & $43 \pm 5.3^{b}$ & $86 \pm 7.2^{b}$ & $146 \pm 6.8^{b}$ & $179 \pm 7.1^{b}$ & $115 \pm 3.1^{\mathrm{d}}$ & $176 \pm 4.3^{\mathrm{d}}$ & $78 \pm 3.4^{\mathrm{d}}$ & $178 \pm 3.2^{\mathrm{d}}$ \\
\hline Group 3 & $54 \pm 3.1^{\mathrm{b}}$ & $76 \pm 4.5^{\mathrm{b}}$ & $173 \pm 7.1^{\mathrm{b}}$ & $184 \pm 6.3^{b}$ & $27 \pm 3.4^{\mathrm{c}}$ & $27 \pm 3.4^{\mathrm{c}}$ & $30 \pm 2.3^{\mathrm{c}}$ & $60 \pm 3.1^{\mathrm{c}}$ \\
\hline
\end{tabular}

note: four male and four female rats were chosen in each group different superscripts within a column indicates significant differences $(\mathrm{P}<0.05)$; no superscripts or same superscripts within a column indicates no significant differences $(\mathrm{P}>0.05)$

On the $7^{\text {th }}$ day, the IGF-I concentration in the blood plasma of groups 1, 2 and 3 was several times greater than in the control group. However, the plasma IGF-I concentration in group 3 on day 14 had declined significantly.

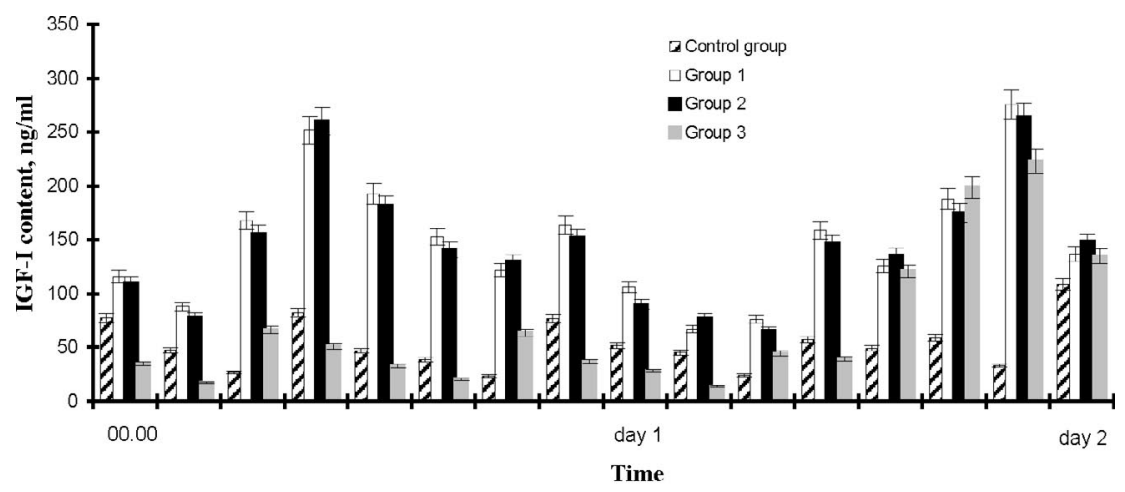

Figure 1. IGF-I Concentration-time diagram in plasma of rats after injection in two days. Vertical bars represent SE 


\section{Growth rate}

The data was subjected to analyses of variance and the effects of PST treatment on body weight are shown in Tables 2 and 3. Administration of PST to

Table 2. Body weight of rats injected ${ }^{1}$ PST and PST liposome at days 0, 7, 14, 28

\begin{tabular}{|c|c|c|c|c|}
\hline \multirow{3}{*}{ Control group } & \multicolumn{2}{|c|}{ Initial weight, $g$} & \multicolumn{2}{|c|}{ Weight on $7^{\text {th }}$ day, $g$} \\
\hline & female & Male & female & male \\
\hline & $137.67 \pm 1.09^{\mathrm{a}}$ & $167.33 \pm 3.62^{\mathrm{a}}$ & $151.77 \pm 2.14^{\mathrm{a}}$ & $201.17 \pm 3.44^{\mathrm{a}}$ \\
\hline Group 1 & $139.5 \pm 2.77^{a}$ & $165 \pm 4.17^{\mathrm{a}}$ & $163.51 \pm 3.00^{\mathrm{b}}$ & $209.68 \pm 4.20^{\mathrm{b}}$ \\
\hline Group 2 & $140.5 \pm 5.87^{\mathrm{a}}$ & $164.83 \pm 2.18^{\mathrm{a}}$ & $164.93 \pm 7.31^{\mathrm{b}}$ & $208.49 \pm 3.09^{b}$ \\
\hline \multirow[t]{3}{*}{ Group 3} & $140.4 \pm 3.81^{\mathrm{a}}$ & $165 \pm 4.33^{\mathrm{a}}$ & $164.1 \pm 3.69^{b}$ & $208.68 \pm 5.53^{b}$ \\
\hline & \multicolumn{2}{|c|}{ Weight on $14^{\text {th }}$ day, $g$} & \multicolumn{2}{|c|}{ Weight on $28^{\text {th }}$ day, $g$} \\
\hline & female & Male & female & male \\
\hline Control group & $176.5 \pm 1.98^{\mathrm{a}}$ & $266.5 \pm 4.35^{\mathrm{a}}$ & $218.83 \pm 5.02^{\mathrm{a}}$ & $337.57 \pm 5.44^{\mathrm{a}}$ \\
\hline Group 1 & $202.17 \pm 1.20^{\mathrm{b}}$ & $279 \pm 6.87^{\mathrm{b}}$ & $236.83 \pm 1.89^{\mathrm{a}}$ & $345.5 \pm 8.41^{\mathrm{a}}$ \\
\hline Group 2 & $204 \pm 6.93^{b}$ & $277.67 \pm 4.03^{\mathrm{b}}$ & $236.33 \pm 7.78^{\mathrm{a}}$ & $347.46 \pm 7.03^{\mathrm{a}}$ \\
\hline Group 3 & $181.67 \pm 4.96^{\mathrm{b}}$ & $264.33 \pm 6.86^{b}$ & $223.33 \pm 3.86^{\mathrm{a}}$ & $332.67 \pm 9.47^{\mathrm{a}}$ \\
\hline
\end{tabular}

values are mean \pm SE. Different superscripts within a column indicates significant differences $(\mathrm{P}<0.05)$; No superscripts or same superscripts within a column means no significant difference $(\mathrm{P}>0.05)$

${ }^{1}$ abdominal cavity injection

control group: injected physiological saline $1 \mathrm{~mL} / \mathrm{d}$; group 1: injected pure PST $1 \mathrm{~mL} / \mathrm{d}(1.2 \mathrm{mg} /$ $\mathrm{mL}$ ); group 2: injected PST liposome $1 \mathrm{~mL} / 7 \mathrm{~d}(8.4 \mathrm{mg} / \mathrm{mL})$; group 3: injected PST liposome 1 $\mathrm{mL} / 7 \mathrm{~d}(16.8 \mathrm{mg} / \mathrm{mL})$

Table 3. Body weight gain of rats injected PST and PST liposome for days 7, 14, 28

\begin{tabular}{|c|c|c|c|c|c|c|}
\hline \multirow{2}{*}{ Item } & \multicolumn{2}{|c|}{ 7days gain, $\mathrm{g}$} & \multicolumn{2}{|c|}{14 days gain, $g$} & \multicolumn{2}{|c|}{28 days gain, $g$} \\
\hline & female & male & Female & male & female & male \\
\hline $\begin{array}{l}\text { Control } \\
\text { group }\end{array}$ & $14.10 \pm 1.65^{\mathrm{a}} 3$ & $3.84 \pm 1.08^{\mathrm{a}}$ & $38.83 \pm 1.59^{\mathrm{a}}$ & $9.17 \pm 1.96^{\mathrm{a}}$ & $81.16 \pm 5.82^{\mathrm{a}}$ & $170.24 \pm 3.13^{\mathrm{a}}$ \\
\hline Group 1 & $24.01 \pm 1.85^{\mathrm{b}} 4$ & $4.68 \pm 3.86^{\mathrm{b}}$ & $62.67 \pm 1.74^{b}$ & $114 \pm 5.33^{b}$ & $97.33 \pm 3.04^{\mathrm{a}}$ & $180.5 \pm 4.63^{\mathrm{a}}$ \\
\hline Group 2 & $24.43 \pm 2.26^{\mathrm{b}} 4$ & $3.66 \pm 3.10^{\mathrm{b}}$ & $63.5 \pm 2.62^{b}$ & $112.84 \pm 2.28^{b}$ & $95.83 \pm 3.13^{\mathrm{a}}$ & $182.63 \pm 5.52^{\mathrm{a}}$ \\
\hline Group 3 & $23.7 \pm 1.27^{b} 4$ & $3.68 \pm 2.38^{b}$ & $41.27 \pm 5.00^{\mathrm{b}}$ & $99.33 \pm 2.97^{\mathrm{b}}$ & $82.93 \pm 2.48^{\mathrm{a}}$ & $167.67 \pm 6.84^{\mathrm{a}}$ \\
\hline
\end{tabular}

female and male rats both in pure PST and PST-liposomes demonstrated that PST increased weight gain. When the dosage was in the range of $5-6 \mathrm{mg} / \mathrm{kg}$ 
(according to body weight), there were no deaths. At this level, the use of PST can be regarded as safe and beneficial. The differences of initial weight between the control and trial groups were not significant $(\mathrm{P}>0.05)$, whereas after 7 days treatment, these differences attained statistical significance, but those between the experimental groups did not $(\mathrm{P}>0.05)$; (Table 2). Similar results were obtained after 14 days of treatment, but after 28 days, the differences of final weight between the control and trial groups were not significant $(\mathrm{P}>0.05)$. PST had a distinctly greater effect on relative body weight gain of male rats than female rats after 7, 14 and 28 days (Figure 2). After 7 and 14 days, the differences

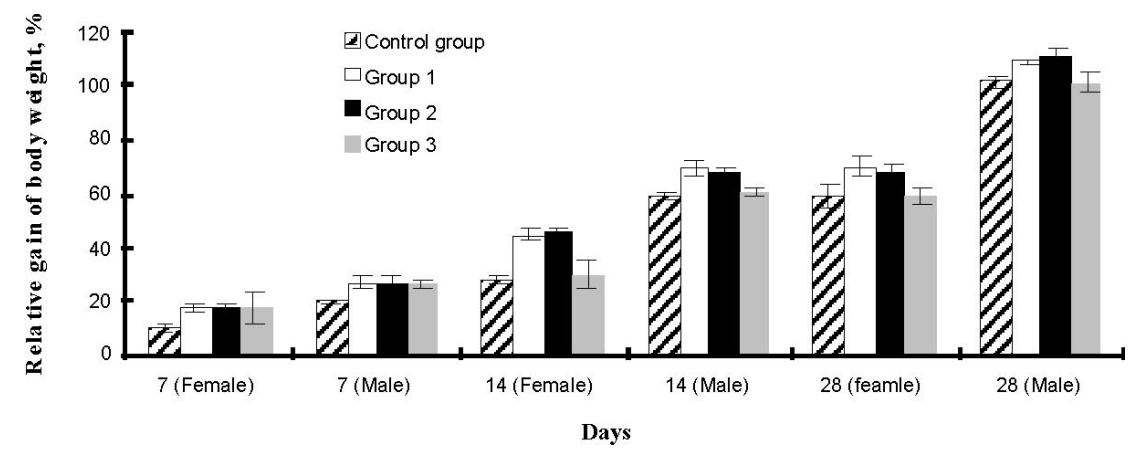

Figure 2. Relative gain of body weight of rats (\%) at day 7, 14, 28. Vertical bars represent SE

in body weight gain between the control and trial groups were significant $(\mathrm{P}<0.05)$, while those between the experimental groups were not $(\mathrm{P}>0.05)$. The differences in body weight gain between the control and trial groups were not significant ( $\mathrm{P}>0.05$ ) after 28 days (Table 3 ).

These results show that PST liposome had a greater sustained-release effect on body weight gain; the period lasted more than seven days.

\section{DISCUSSION}

The results reveal that pure PST and PST liposome promote growth of female and male rats. Moreover, the effects of promoting weight gain by PST and PST liposome are different between the sexes; males gain distinctly more than females. The treatment groups showed an increase $(\mathrm{P}<0.05)$ relative to the control group. PST liposome was effective with sustained-release effects that lasted more than 7 days. The study by Xu et al. (2005) also demonstrated by RIA that the PST concentration in the blood plasma of a group injected PST liposome remained 
on a sustained level for 7 days, which is in agreement with the results of $\mathrm{Li}$ et al. (2003). The IGF-I concentration was several times greater than the control level.

The range of biological effects of PST is extraordinary and has been discussed previously (Rehfeldt et al., 2001). Early studies by Lary established that PST worked in pigs (Harrelll et al., 1996; Etherton, 2000). PST has impressive effects on growth. The extent to which this occurs is illustrated by studies in which maximally effective doses of PST ( $\approx 100 \mu \mathrm{g} / \mathrm{kg}$ of body weight per day) have been administered to growing pigs (for 30 to $77 \mathrm{~d}$ ). These studies revealed that the growth rate increased approximately 10 to $20 \%$, feed efficiency (feed consumed/ body weight gain) improved 13 to $33 \%$, and protein deposition (muscle growth) increased by as much as $62 \%$.

It has been reported that GH stimulated fibroblast growth. The effect of locally applied GH on insulin-like growth factor (IGF-I) mRNA concentration and granulation tissue formation was studied by Steenfos and Jansson (1992). The concentration of IGF-I mRNA in ingrown granulation tissue as well as the wet weight of this tissue were significantly higher in the GH-treated cylinders. There was no significant effect of GH on IGF-I receptor mRNA and GH receptor mRNA levels. The results of the study showed that GH stimulated granulation tissue formation and increased the concentration of IGF-I mRNA in the ingrown granulation tissue. The effects of growth hormone $(\mathrm{GH})$ and dietary protein on expression of IGF-I and GH receptor (GHR) genes in liver, muscle, and fat of pigs were also investigated by Brameld et al. (1996). The study demonstrated tissuespecific control of expression of the two genes and also tissue-specific promoter usage in response to $\mathrm{GH}$ administration. These results were consistent with the results of our studies.

Despite these findings, little is known about the exact metabolic pathways of PST liposome which mediates the effects on adipose tissue lipogenesis. PST liposomes demonstrated a greater sustained-release effect, which lasted more than seven days in our study, however, further studies need to be conducted to precisely define how long the sustained-release effect can be maintained and if an oral preparation is feasible in the future.

\section{REFERENCES}

Bangham A.D., Standish M.M., Watkins J.C., 1965. Diffusion of univalent ions across the lamellae of swollen phospholipids. J. Mol. Biol. 13, 238-252

Betageri G.V., Rogers J.A., 1987. Thermodynamics of partitioning of -blockers in the n-octanolbuffer and liposome systems. Int. J. Pharm. 36, 165-173

Brameld J.M., Atkinson J.L., Saunders J.C., Pell J.M., Buttery P.J., Gilmour R.S., 1996. Effects of growth hormone administration and dietary protein intake on insulin-like growth factor I 
and growth hormone receptor mRNA expression in porcine liver, skeletal muscle, and adipose tissue. J. Anim. Sci. 74, 1832-1841

Chen L.F., Zhang X.Y., Yang Y.S., 1999. Making liposome and application in veterinary. Sino Vet. Parasitic. Dis. PRC, 7, 56-59

Crommelin D.J.A., Storm G., Jiskoot W., Stenekes R.J.H., Mastrobattista E., Hennink W.E., 2003. Nanotechnological approaches for the delivery of macromolecules. J. Control Release 87, 8188

Etherton T.D., 2000. The biology of somatotropin in adipose tissue growth and nutrient partitioning. J. Nutr. 130, 2623-2625

Evans H.M., Simpson M.E., 1987. Hormones of the anterior hypophysis. Amer. J. Physiol. 98, 511523

Harrelll R.J., Dwyer D.A., Matitashvili E., Bauman D.E., 1996. Effect of exogenous porcine somatotripin in adipose tissue metabolism in young growing pigs. J. Anim. Sci. 74, Suppl., 143 (Abstr.)

Harris D.M., Dunshea F.R.,. Bauman D.E., Boyd R.D., Wang S.Y., Johnson P.A., Clarke S.D., 1993. Effect of in vivo somatotropin treatment of growing pigs on adipose tissue lipogensis. J. Anim Sci. 71, 3293-3300

Huth U., Wieschollek A., Garini Y., Schubert R., Peschka-Süss R., 2004. Fourier transformed spectral bio-imaging for studying the intracellular fate of liposomes. Cytometry A, 57A, 10-21

Li Z., Gao M., Yu R.S., Zhang D.F., Liu H.L., Zhou Z.A., 2003. Preliminary study on extendedrelease of $\mathrm{pGH} /$ liposome and its body weight increase effect on hypophysectomized rats. Acta Agr. Shanghai. 19, 107-108

Mildner A.M., Clarke S.D., 1991. Porcine fatty acid synthase: cloning of a comlementary DNA, tissue distribution of its mRNA and suppression of expression by somatotropin and dietary protein. J. Nutr. 121, 900-907

Rehfeldt C., Kuhn G., Vanselow J., Furbass R., Fiedler I., Nurnberg G., Clelland A.K., Stickland N.C., Ender K., 2001. Maternal treatment with somatotropin during early gestation affects basic events of myogenesis in pigs. Cell Tissue Res. 306, 429-440

Sejrsen K., Oksbjerg N., Vetsergaard M., Sorensen M.T., 1995. Growth hormone and related peptides as growth promoters. In: Proceedings of Scientific Conference on Growth Promotion in Meat Production. Brussels (Belgium). The European Commission, pp. 87-119

Steenfos H.H., Jansson J.O., 1992. Growth hormone stimulates granulation tissue formation and insulin-like growth factor-I gene expression in wound chambers in the rat. J. Endocrinol. 132, 293-298

Turman E.J., Andrews F.N., 1955. Some effects of purified anterior pituitary growth hormone on swine. J. Anim. Sci. 14, 7-18

Wolverton C.K., Azain M.J., Duffy J.Y., White M.E., Ramsay T.G., 1992. Influence of somatotropin on lipid metabolism and IGF-I gene expressionin porcine adipose tissue. Amer. J. Physiol. 263, E637-E645

Xu C.L., Ji C., Hao K., Li X.Q., Yao H.Y., 2005. Studies on pharmacokinetic of porcine somatotropin liposomes. Chem. Res. Chinese Univ. 21, 187-190 